Research Article

\title{
Linking Zoopharmacognocy with Ethnomedication, An Evidence Base from Sebangau National Park, Central Kalimantan Indonesia
}

\author{
Adventus Panda *, Yohanes Edy Gunawan \\ Zoology Laboratory, Faculty of Teaching and Education, University of Palangka Raya, Palangkaraya 73111A, \\ Indonesia
}

\section{Article history:}

Submission March 2018

Revised August 2018

Accepted September 2018

*Corresponding author:

E-mail: apanda@fkip.upr.ac.id

\begin{abstract}
The ability of animal to perform self-medication has been studied decades, as well as their relationship with medication practices by communities. Long-term observation of Orangutans' behaviour (Pongo pygmaeus wurmbii), by communities surround Sebangau National Park, has suggested as their modes to today ethno-medication practice. The study was aimed to study the relationship of Orangutans selfmedicate behavior with ethno-medication practice, in Sebangau area. The research was conducted in Punggualas, SNP, from 29 April to 03 October 2017. A number of 13 traditional healers $(\mathrm{TH})$ from Karuing $(\mathrm{n}=4)$, Baun Bango $(\mathrm{n}=4)$, and Jahanjang $(\mathrm{n}=5)$ have been interviewed. All plants are listed and photograph. Plants parts, and their mechanism of utilization were also kept for record. Meanwhile, the behavior followed the Orangutan protocol, with focus on their feeding behavior. All data were analyzed descriptively, while the relationship was analyzed using chi-square and $\mathrm{F}$ test. We have recorded a total 131 plants at various life forms, in Baun Bango ( $\mathrm{n}=59)$, Jahanjang $(\mathrm{n}=41)$, and Karuing $(\mathrm{n}=21)$. Plants that were found similar among three villages, removed, were only 95 left. We observed one female, showing the ability to perform self-mediaction. It is characterized by selectively choosing young leaves of Mezzetia sp., pulp of the Dyera lowii and Ilex cymosa, and lastly chew the entire leaves of Belang Handipek. It suggests a form of prevention against fatigue conditions, and the combination of these three plants species assume to be relating to fitness. This study shows that there is a relationship between the plant part used by the traditional healer and the orang- utan $\left(x^{2}=43,887 ; n=115, d f=11\right.$, p-value $\left.=0.0000\right)$, the relationship between the use of plant parts utilized by the traditional healer and orangutans ( $\mathrm{x}^{2}$ $=15,647 ; \mathrm{n}=50, \mathrm{df}=8$, $\mathrm{p}$-value $=0.0000$ ). Furthermore, there is a relationship between the practice of traditional healer treatment using plant parts and Orangutan $\left(F_{1,113}=230.158\right.$; p-value $\left.=0,000\right)$. The study urges to isolate secondary metabolites for further investigation, especially in terms of phyto-pharmacy.
\end{abstract}

Keywords: Zoopharmacognocy, ethno-medicine, Pongo pygmaeus wurmbii, Sebangau National Park

\section{Introduction}

Zoopharmacognosy is the ability of animals to perform self-medication. The basic premise of this terminology implies that animals make use of the secondary and/or non-nutritional components of plants to treat themselves [1]. Furthermore [2] reported that in general this method of self-medication is divided into two classes, namely prophylactic and therapeutic.
This capability has been well documented since 1987 in one of the great apes, the Chimpanzees $[3,4]$ and the other apes [5, 6, 7, 8]. Several studies related to these abilities in the bird taxa [9, $10,11]$. Hence, it is suggested that the behavior of Orangutans in performing self-medication are reflects the medication practice of communities surround Sebangau National Park been practice today. 


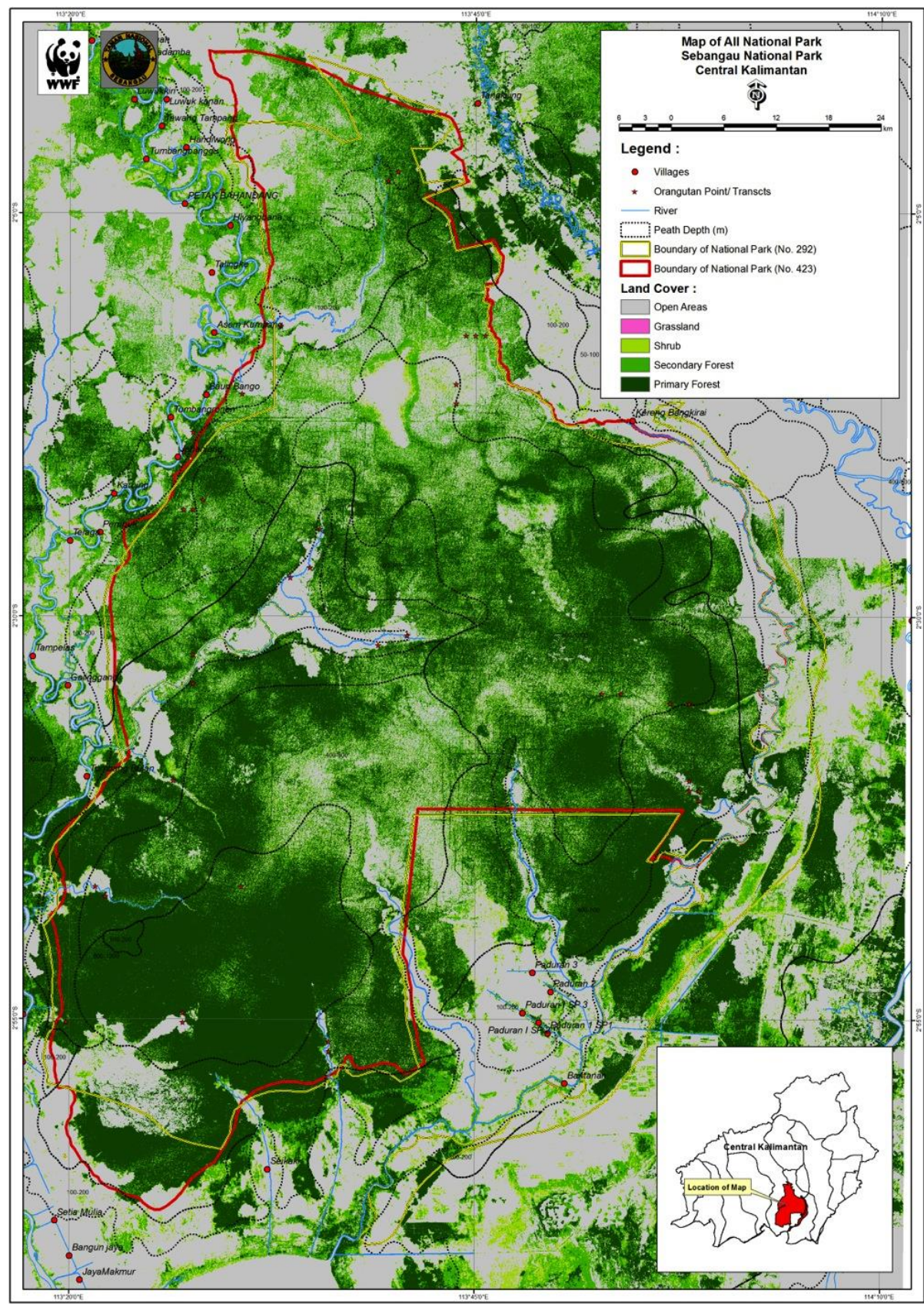

Figure 1. The map of Sebangau National Park, Central Kalimantan, Indonesia (Source: WWF-Indonesia, Central Kalimantan)

The term ethno-medication in many academic literatures has different meanings, such as causes of, diagnosis and treatment a disease as well as the level of health status. This, in turn provided ineffectiveness for reliable insight of relevant literature $[12,13]$. Several studies have suggested the fact that there are similarities in the selection of plant parts by animals and humans. The use of soft plant tissue of Vernonina amygdalina Del. (Compositae) by Chimpanzees (Pan troglodytes) and
Mahale communities, Africa, to address complaints of nematode worms [2]. Furthermore, the same pattern reported for Commelina sp. (Commelinaceae) by Orangutan (Pongo pygmaeus wurmbii) and communities in Sebangau, Central Kalimantan [14]. Hence, we apply definition of ethno-medication [13] which is the practice or application of knowledge related to the field of study in medical word for a particular tribe/culture. The study was aimed to study the relationship among 


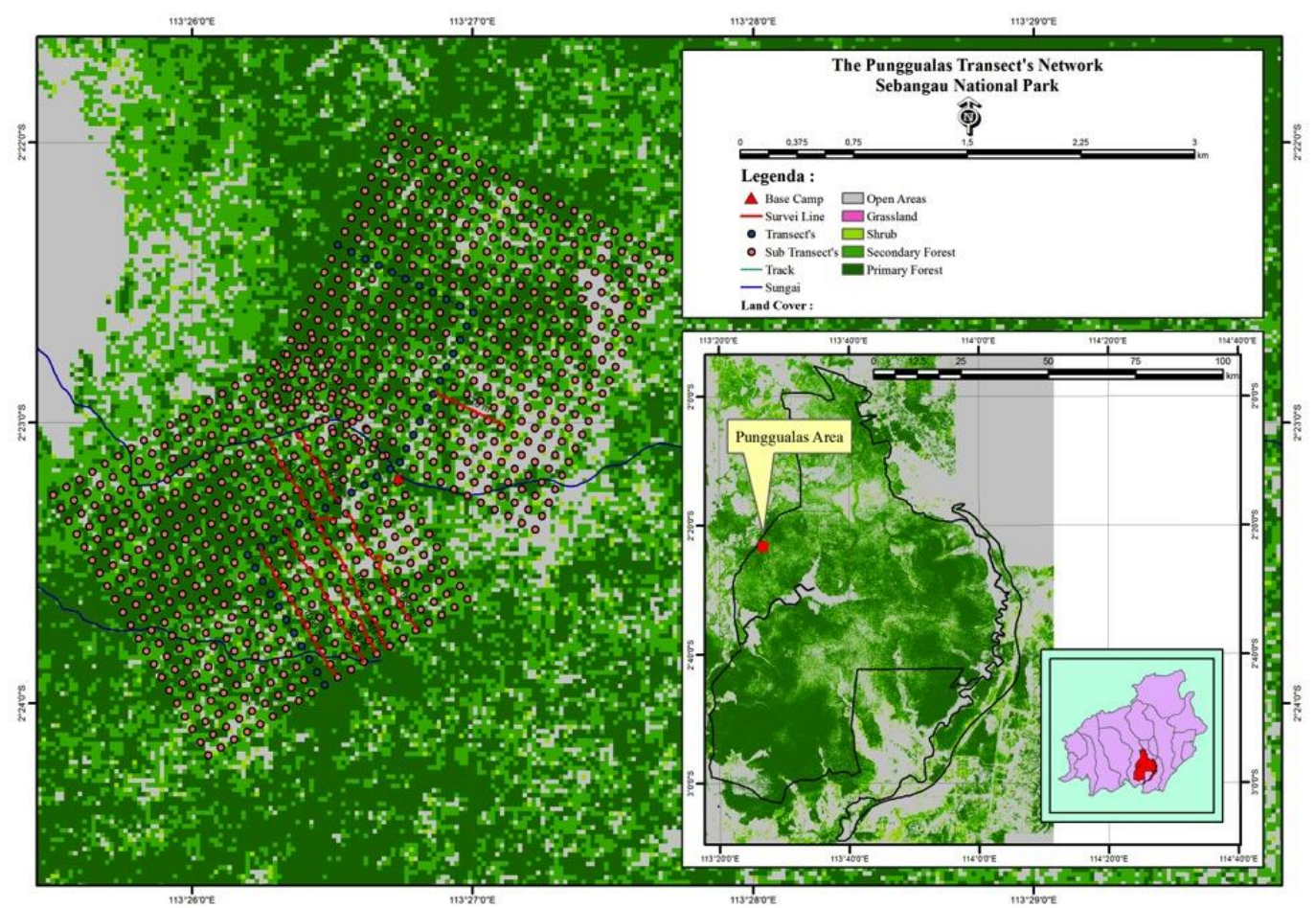

Figure 2. Transects network of Orangutan behavior observation, Punggualas Research Station (Source: WWFIndonesia, Central Kalimantan)

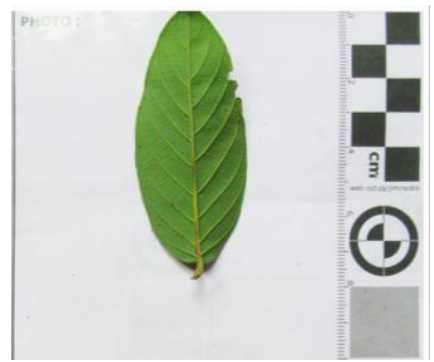

(a)

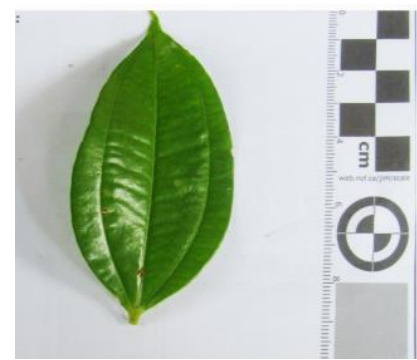

(b)

Figure 3. Leaves (a) U. gambir Roxb. and (b) P. galeata Ridl. (Sample collected from Baun bango village)

the utilization of plant parts used, utilized and forms of treatments by the Traditional Healer (TH) and Orangutan (P. p. wurmbii) in Sebangau National Park (SNP).

\section{Material and Methods}

Research is conduct using concurrent embedded method. Field data was collected from April 22 to October 3, 2017. There are two methods deploy, regarding the characteristic of the subjects, which are as follows:

\section{Zoopharmacognosy of the orangutan (P. p. Wurmbii)}

The observation of Orangutan behaviour was carried out in Punggualas area, following Russon et al. (2008) [11]. It is located in the western site of Sebangau National Park (Figure 1). It is a wildlife research station, with their flagship species is Orangutan (P. p. wurmbii), which is managed by SNP in cooperation with WWF-Indonesia Central Kalimantan. The observations are using grid system. In Punggualas (Figure 2), there are four main transects, on which each having a length of 1,000 $\mathrm{m}$. Within each main transect, we divided each $100 \mathrm{~m}$, so that the intersection of each path, yields a grid of $100 \times 100 \mathrm{~m}\left(10,000 \mathrm{~m}^{2}=1 \mathrm{Ha}\right)$. Thus, the study area is $4 \times 100 \times 10,000 \mathrm{~m}^{2}=4,000,000$ $\mathrm{m}^{2}$ (400 Ha). The team regularly travels through the main transect, looking for signs of orang-utan 


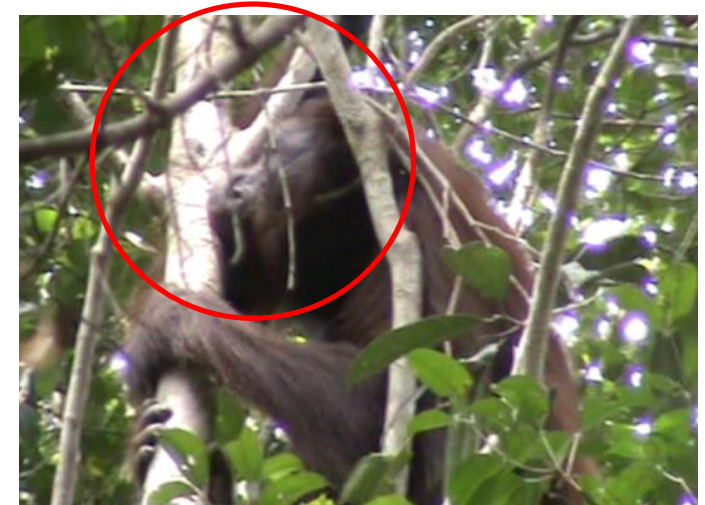

(a)

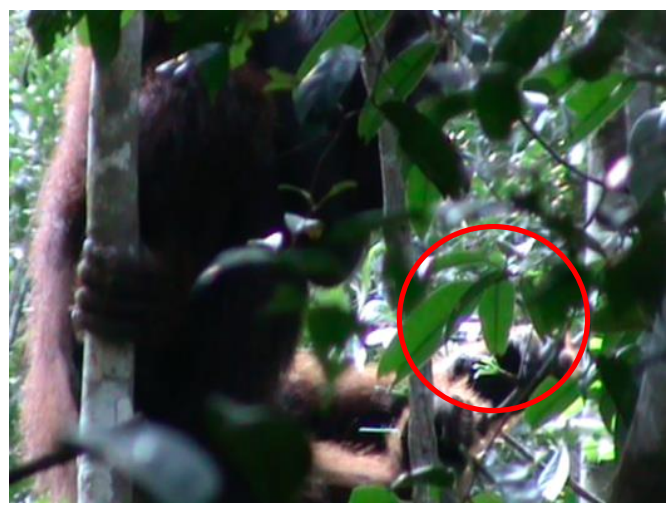

(c)

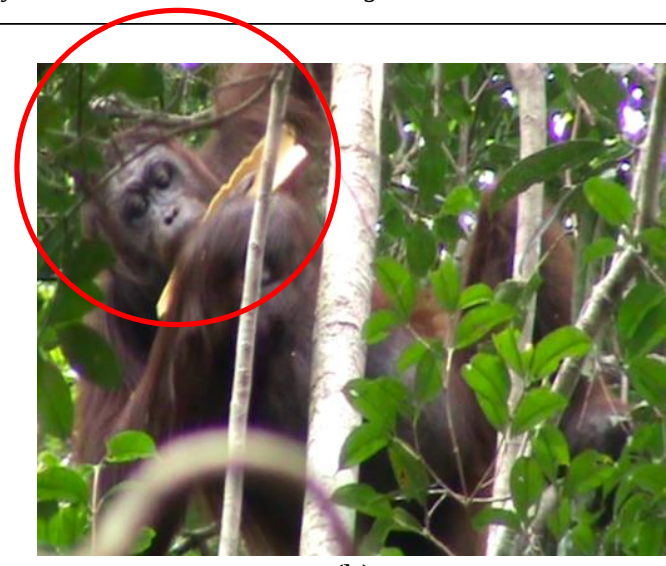

(b)

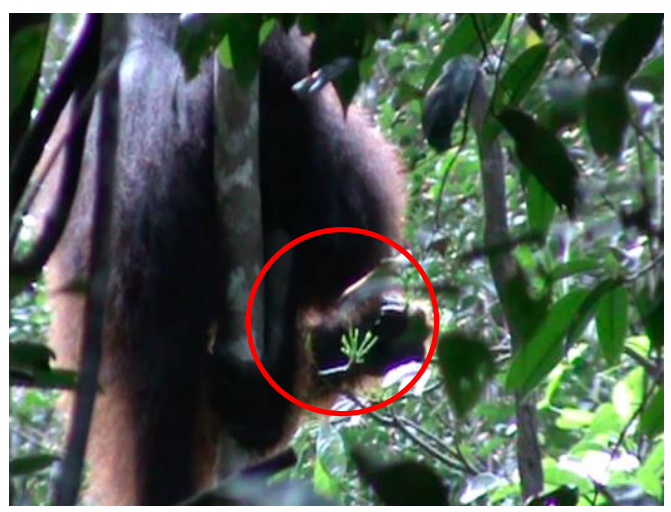

(d)

Figure 4. Observed behavior of Orangutans feed on plant parts instead of natural diet (a and b) Orangutans bite stems I. cymosa stems - take a layer between the outer skin and the cambium; (c and d) Orangutans eat flowers of S. macrophylla

presence.

\section{Ethnomedicine}

In-depth interviews, as well as questionnaires were conducted in Baun Bango, Jahanjang and Karuing Villages, Katingan District. Among those villages, traditional healer $(\mathrm{TH})$ - he or she, shall pass the inclusion criteria, as follow a) are confidently acquired knowledge from their descendant, pass to generations; $b$ ) the plants are collected surrounding SNP area, as well as indicate the location; c) demonstrate plant parts processing before hands.

\section{Results and Discussion}

The total plant species used by THs for their medication practices, within three villages was 131, whereas, Bango Village $(n=59)$, Jahanjang Village $(n=41)$ and Karuing $(n=21)$ respectively. Since we have found similar species among villages, same species will only be count as one. Thus, the total plant species studied were 95 species.
Meanwhile, during the observation, the Orangutan feed on 23 species of plants. The top four species have been recorded is Kamasira (Ilex cymosa), Mahoni Baputi (Switenia macrophylla), Bajakah Kalalawit (Uncaria gambir Roxb), and Kamasulan (Pternandra galeata Ridl.). The two latter mentioned was the same on which Orangutan and THs, were incidentally, utilized (Figure 3 and 4).

Meanwhile, bajakah kalalawit (U. gambir Roxb.), TH believed to be a cure for internal medicine, by drinking its latex, while for the Orangutans there has been no explanation of the benefits of this plant. The bajakah kalalawit (U. gambir Roxb.) as another research reported that it has the phenolic contents and antibacterial properties of various extract [15]. Furthermore, a research suggested that this species, according to the detailed analysis, has an active compound so-called catechin [16]. It is a group occupies and intermediary position in the tannin hierarchy as 'a family of catechin tannin'. While another research mentioned 
Table 1. Ethno-medicinal use of U. gambir Roxb and P. galeata Ridl, in Baun Bango (BB), Karuing (KR) and Jahanjang (JHJ), Kamipang District, Katingan Regency Central Kalimantan Indonesia

\begin{tabular}{|c|c|c|c|c|c|}
\hline Species name & Family & $\begin{array}{l}\text { Sample } \\
\text { from }\end{array}$ & Applications & $\begin{array}{c}\text { Plant } \\
\text { part }\end{array}$ & Remarks \\
\hline $\begin{array}{l}\text { U. gambir } \\
\text { Roxb. }\end{array}$ & Rubiaceae & $\mathrm{BB}$ & $\begin{array}{l}\text { Stem was cut, latex collected } \\
\text { and drinks. }\end{array}$ & Latex & $\begin{array}{l}\text { An illness (related } \\
\text { to internist) }\end{array}$ \\
\hline \multirow[t]{3}{*}{$\begin{array}{l}\text { P. galeata } \\
\text { Ridl. }\end{array}$} & Melastomaceae & $\mathrm{BB}$ & $\begin{array}{l}\text { Root treat by pressed, mix } \\
\text { with powder, apply to target } \\
\text { area (suspect); } \\
\text { some will treat by chewing }\end{array}$ & Roots & $\begin{array}{l}\text { Tumor; haemor- } \\
\text { rhage }\end{array}$ \\
\hline & & KRG & $\begin{array}{l}\text { Roots directly eaten, while } \\
\text { leaves used sauna-like treat- } \\
\text { ment }\end{array}$ & $\begin{array}{l}\text { Roots; } \\
\text { Leaves }\end{array}$ & Haemorrhage \\
\hline & & $\mathrm{JHJ}$ & Sauna-like treatment & Leaves & Haemorrhage \\
\hline
\end{tabular}

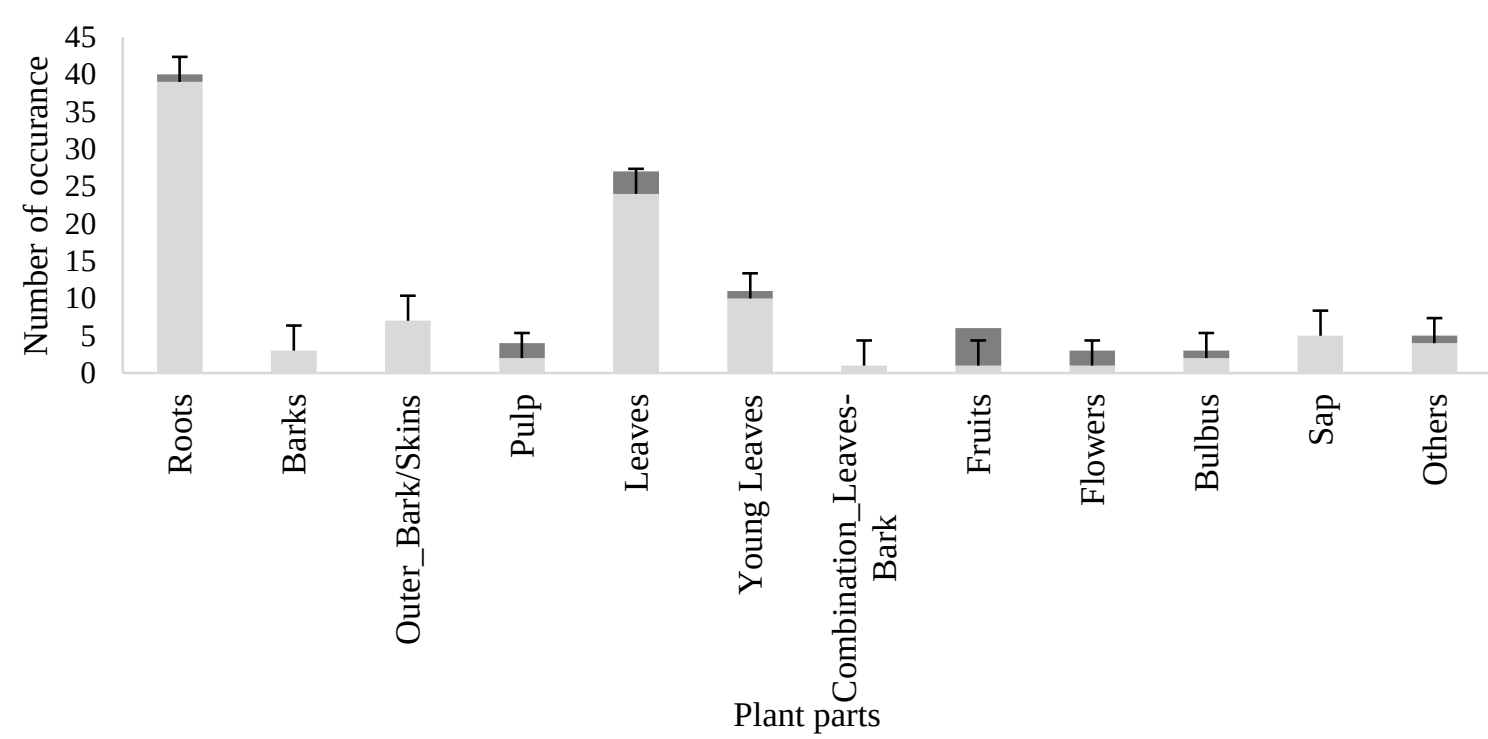

(a)

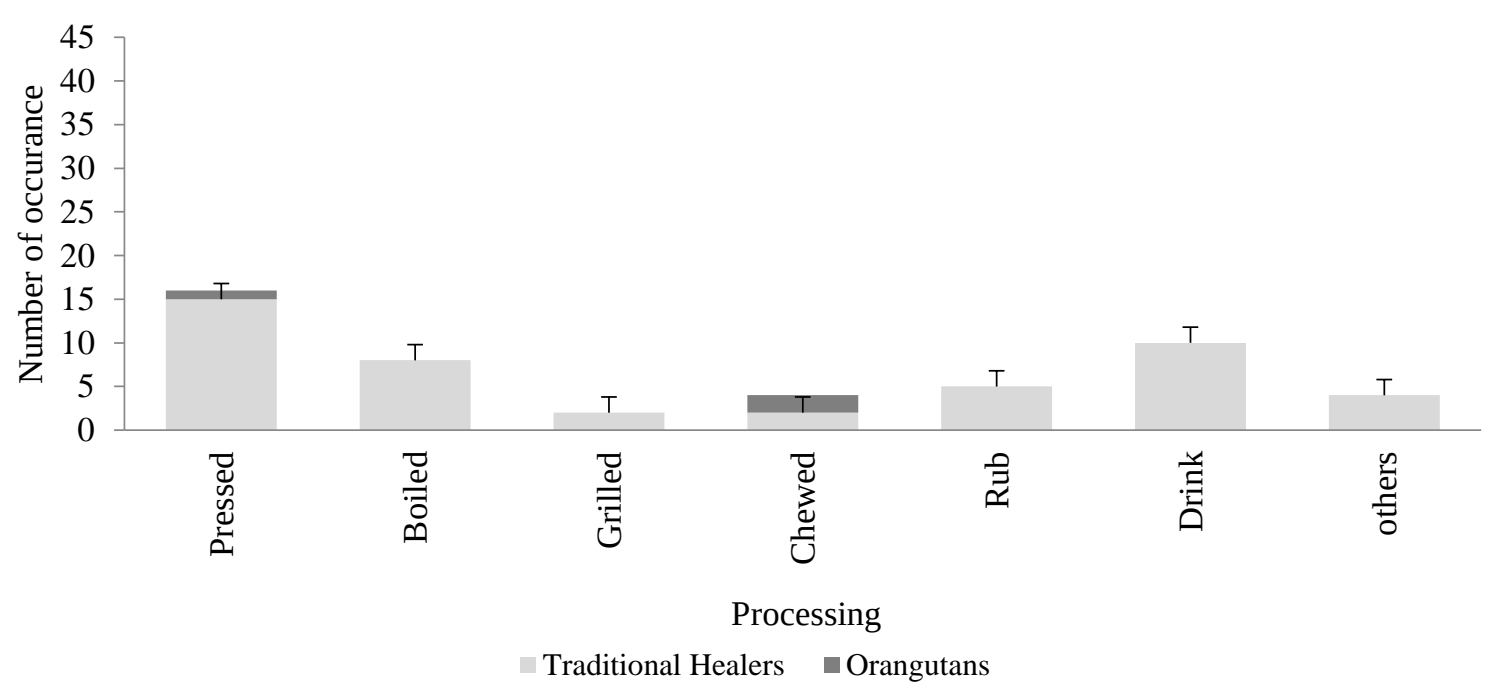

(b)

Figure 5. The comparisons on plant parts used (a) and utilized (b) between orangutans and traditional healers 
that phenolic compounds have an astringency and reduce digestibility effect [3].

To test the relationship between the plant part and the mode of utilization, both by the $\mathrm{TH}$ and orangutans, one-way ANOVA and Chi-square tests were performed. Plant parts used by both of them are root, epidermis, leaf (including young leaves), fruits, and flowers respectably (Figure 5a). Correlation value for plant part used by $\mathrm{TH}$ and orangutans $\mathrm{x}^{2} 43.887 ; \mathrm{n}=115, \mathrm{df}=11$, $\mathrm{p}$ value $=0.0000$. In addition, there are several other non-plant parts for Orangutans i.e., termites. Although, this may reflect items at small quantities, as compares to concept of preference, this seems promising. The result indicates that non-nutritional parts are at stage, as a research pointed out that leaves and barks electivity values of the mostpreferred species are orders of magnitude higher than for the least-preferred species [17].

Figure $5 \mathrm{~b}$ have revealed some of the most prominent and show similarities associated with utilize is pressed and chewed plant parts, with $\mathrm{x}^{2}=$ 15.647, $\mathrm{n}=50, \mathrm{df}=8$, $\mathrm{p}$-value $=0.0000$. Chewing process is thought to be the activation mechanism of a plant secondary metabolite compound involving the enzyme present in saliva [13].

One-way Anova shows that there is a correlation between medicinal treatment practice using plant part and Orangutan $\left(\mathrm{F}_{(1,113)}=230,158 ; \mathrm{n}=\right.$ 114; $\mathrm{p}$-value $=0.000$ ). This indicates that there is a secondary metabolite in the plant, which has a preventive and/or curative effect. We do concern about ethno-medication aspects as well as the nature of secondary metabolite pathway both in human and non-human primates. These findings lead to further investigation involving simultaneous and synergetic pattern with other compounds. Nevertheless, mechanism on which the metabolite trigger factor as well as its determine factor.

\section{Conclusion}

Based on the results of the data analysis, it can be concluded that there is a relationship between the utilization of plant parts, used $\left(x^{2}=43,887 ; n\right.$ $=115$, df $=11$, p-value $=0.0000)$, utilized $\left(x^{2}=\right.$ $15,647 ; \mathrm{n}=50, \mathrm{df}=8$, p-value $=0.0000)$ and the treats to plant parts $(\mathrm{F}=230,158$; $\mathrm{df}$ error $=113$; $\mathrm{p}$-value $=0.000$ ) by the Orangutan and traditional healers.

\section{Acknowledgment}

Thanks to Mr. Alwi Gapur, Achmad, Maskor, Sarwepin, Sarjuyo; and Mrs. Haniah, Marliana, Norhanah, Norma, Norsi, Rasiah, Rusliana and Rustini are consciously willing to provide information about the practice of treatment with plant material. Rosenda Chandra Kasih, Program Manager of WWF-Indonesia Central Kalimantan, for input on the substance of the discussion, Head of Sebangau National Park Office, Yuliansyah; Tica Yulica, Herianto and Depie. The FKIP-UPR Zoology Laboratory personnel, Freshyumander Patianom, Ronny Octobery, and all those personnel who cannot be mentioned one after another.

\section{References}

1. Huffman MA (1997) Current evidence for self-medication in primates: A multidisciplinary perspective. Yearbook of Physical Anthropology 40: 171 - 200.

2. Carlos-Neto EM (2012) Zoopharmacognosy, the self-medication behaviour of animals Interfaces Cientificas - Saude e Ambiente 1 (1): 61 - 72. doi: 10.17564/2316-3798.2012v1n1p6172.

3. Huffman MA (2003) Animal self-medication and ethno-medicine: Exploration and exploitation of the medicinal properties of plants. Proceedings of the Nutrition Society 62 (2): 371 - 381. doi: 10.1079/PNS2003257.

4. Huffman MA, Hatoshi S (2004) An experimental study of leaf swallowing in captive chimpanzees: Insight into the origin of self-medicative behaviour and the role of social learning. Primates 45 (2): 113 - 118. doi: 10.1007/s10329-003-0065-5.

5. Clark CC, Clark L, Clark (1990) “Anting” behavior by common grackles and starlings. Wilson Bulletin 102 (1): 167 - 169.

6. Baker M (1996) Fur rubbing: Use of medicinal plants by capuchin monkeys (Cebus capucinus). American Journal of Primatology 38 (3): 263 - 270. doi: 10.1002/(SICI)10982345(1996)38:3<

263::AID-AJP5>3.0.CO;2-X

7. Dejoseph M, Taylor RS, Baker M, Aregullin M (2002) Fur-rubbing behaviour of capuchin monkeys. Journal of Academic Dermatology 46 (6): 924 - 925. doi: 10.1067/mjd.2002.119668.

8. Verderane MP, Falotico T, Resende BD et al. (2007) Anting in semi free-ranging group of Cebus apella. International Journal of Primatology 28: 47 - 53. doi: 10.1007/s10764-006-9102-8.

9. Clark L, Mason JR (1985) Use of nest material as insecticidal and anti-pathogenic agents by the European starling. Oecologia 67 (2): 169 - 176. doi: 10.1007/BF00384280.

10. Clark L, Mason JR (1987) Olfactory discrimination of plant volatiles by the European starling. Animal Behaviour 35 (1): 227 235. doi: 10.1016/S0003-3472(87)80228-2. 
11. Russon AE, Wich SA, Ancrenaz M et al. (2009) Geographic variation in orangutan diets. In: Wich SA, Utami SS, Setia TM, van Schaik CP (Eds.) Orangutans: Geographic variation in behavioral ecology and conservation. Oxford, Oxford University Press. pp 135 - 156. doi: 10.1093/acprof:oso/9780199213276. 001.0001.

12. Quinlan MB (2011) Ethnomedicine. In: Singer M, Erickson PI (Eds.) A companion to medical anthropology 1st edition. New Jersey, Blackwell Publishing Ltd. pp 381 - 403.

13. Mansouri A, Sarayani A, Ashouri A et al. (2015) Is 'self-medication' a useful term to retrieve related publications in the literature? A systematic exploration of related terms. PLoS ONE 10 (5): e0125093. doi: 10.1371/journal.pone.0125093.
14. Morrogh-Bernard HC (2008) Fur-Rubbing as a form of selfmedication in Pongo pygmaeus. Internationl Journal of Primatology 29: 1059 - 1064. doi: 10.1007/s10764-008-9266-5.

15. Pambayun R, Gardjito M, Sudarmadji S, Kuswanto KR (2007) Phenolic content and antibacterial properties of various extract of gambir (Uncaria gambir Roxb.). Indonesian Journal of Pharmacy 18 (3): 141 - 146.

16. Setyowati H (2017) Gambir (Uncaria gambir Roxb.) as natural cosmeceutical agent. CDK 25044 (3): 222 - 224.

17. Harrison ME (2009) Orangutan feeding behaviour in Sabangau, Central Kalimantan. PhD Dissertation. Cambridge University. Wildlife Research Group. 
This page is intentionally left blank. 